\author{
Magdalena Mosionek-Schweda, Monika Szmelter \\ Uniwersytet Gdański \\ e-mails: magdams@ug.edu.pl; monika.szmelter@wp.pl
}

\title{
ZIELONE OBLIGACJE - NOWY INSTRUMENT FINANSOWANIA INWESTYCJI POLSKIEGO RZĄDU
}

\section{GREEN BONDS - A NEW INSTRUMENT FOR FINANCING INVESTMENT OF THE POLISH GOVERNMENT}

DOI: $10.15611 /$ pn.2018.532.21

JEL Classification: G15, G23, H63, Q56

Streszczenie: Celem artykułu jest prezentacja emisji pierwszych na świecie skarbowych zielonych obligacji przeprowadzonych przez Polskę na rynkach zagranicznych oraz ocena rentowności tych instrumentów w porównaniu do klasycznych obligacji, o podobnych do green bonds parametrach, emitowanych przez państwo polskie na rynkach zagranicznych. W opracowaniu przyjęto hipotezę, iż polskie skarbowe zielone obligacje charakteryzują się wyższą rentownością w terminie do wykupu niż klasyczne obligacje rządowe emitowane przez Polskę na rynkach zagranicznych. W badaniu wykorzystano wskaźniki rentowności obligacji oraz ceny tych instrumentów. Dane do badania zaczerpnięto z serwisu informacyjnego Eikon Thomson Reuters. Przyjęta w opracowaniu hipoteza została zweryfikowana pozytywnie, gdyż obligacje zielone cechowały się, podczas prawie całego okresu analizy, wyższymi poziomami wskaźnika rentowności w terminie do wykupu niż klasyczne zagraniczne obligacje skarbowe o zbliżonym czasie życia.

Słowa kluczowe: zielone obligacje, obligacje skarbowe, rentowność obligacji, zrównoważony rozwój.

Summary: The aim of the article is to present the issuance of the world's first green bonds carried out by Poland on foreign markets and to assess the profitability of these instruments compared to classic bonds with similar to green bond parameters issued by the Polish state on foreign markets. The study adopted a hypothesis that Polish Treasury green bonds are characterized by higher yield to maturity than the traditional government bonds issued by Poland on foreign markets. The study was based on data derived from the Eikon Thomson Reuters information service. The hypothesis adopted in the study was verified positively, because green bonds were characterized during almost the entire analysis period with higher levels of the return on maturity than classic Treasury bonds with a similar life time.

Keywords: green bonds, Treasury bonds, bond yield, sustainable development. 


\section{Wstęp}

Idea zrównoważonego rozwoju gospodarczego respektującego środowisko naturalne od dawna jest dyskutowana na forum międzynarodowym, jednocząc rządy, międzynarodowe oraz krajowe instytucje i organizacje we wspólnych inicjatywach podejmowanych na rzecz ochrony środowiska. Jednakże wdrożenie idei zrównoważonej i bardziej ekologicznej gospodarki wymaga znacznych nakładów finansowych na projekty korzystne dla środowiska. Wyniki analiz przeprowadzonych na zlecenie Komisji Europejskiej wskazują, że Unia Europejska potrzebuje rocznie około 180 mld EUR na dodatkowe inwestycje, aby osiągnąć cele środowiskowe i wywiązać się z unijnych zobowiązań zawartych w Porozumieniu paryskim z 12 grudnia 2015 r. [European Commission 2018, s. 2]. W związku z tym, że inwestycje środowiskowe wymagają zwykle długoterminowego finansowania, dobrym źródłem pozyskiwania tych środków jest rynek kapitałowy, a także rynek instrumentów dłużnych jako alternatywa dla kredytów bankowych czy emisji akcji. W praktyce rynek tzw. zielonych obligacji (green bonds) pojawił się w latach 2007-2008 wraz z pierwszymi emisjami przeprowadzonymi przez Europejski Bank Inwestycyjny oraz Bank Światowy. Emitenci z sektora prywatnego dołączyli do tego rynku w latach 20132014 i od tego momentu wartość emisji zielonych obligacji stale rośnie o ok. 120\% rocznie [Bieliński, Mosionek-Schweda 2018, s. 14.]. Pierwsze skarbowe zielone obligacje (sovereign green bonds) zostały wyemitowane dopiero pod koniec $2016 \mathrm{r}$. Emitentem tych instrumentów była Polska, wpisując się tym samym w historię rozwoju światowego rynku finansowego. Kilkanaście miesięcy później polskie Ministerstwo Finansów przeprowadziło kolejną emisję zielonych obligacji, w efekcie czego Polska ponownie stała się pionierem na rynkach finansowych, tym razem jako pierwszy na świecie państwowy emitent plasujący drugą emisję green bonds.

Celem artykułu jest prezentacja emisji pierwszych skarbowych zielonych obligacji przeprowadzonych przez Polskę na rynkach zagranicznych oraz ocena rentowności tych instrumentów w porównaniu do klasycznych obligacji, o podobnych do green bonds parametrach, emitowanych przez państwo polskie na rynkach zagranicznych. W opracowaniu przyjęto hipotezę, iż polskie skarbowe zielone obligacje charakteryzują się wyższą rentownością w terminie do wykupu niż klasyczne obligacje rządowe emitowane przez Polskę na rynkach zagranicznych.

\section{Charakterystyka emisji polskich skarbowych green bonds}

Jak wspomniano, Polska zapisała się w historii rozwoju światowego rynku zielonych obligacji jako pierwszy na świecie rządowy emitent tych instrumentów oraz pierwsze państwo emitujące skarbowe green bonds dwukrotnie. W tabeli 1 zestawiono wybrane parametry obu emisji.

Pierwsza emisja polskich skarbowych zielonych obligacji nastąpiła pod koniec grudnia 2016 r. Ministerstwo Finansów planowało wówczas sprzedać papiery o war- 
tości 500 mln EUR, niemniej jednak ze względu na duże zainteresowanie inwestorów tą emisją i popyt wynoszący ok. 1,5 mld EUR ostatecznie zwiększono kwotę wyemitowanych obligacji do $750 \mathrm{mln}$ EUR, uzyskując rentowność na poziomie 0,634\%, przy stałym kuponie wynoszącym 0,5\% [List Emisyjny nr 67/2016]. Warto zauważyć, że emisja tych szczególnych instrumentów przyczyniła się do dywersyfikacji bazy inwestorów lokujących w obligacje skarbowe Polski, ponieważ $61 \%$ emisji nabyli inwestorzy specjalizujący się $\mathrm{w}$ inwestycjach $\mathrm{w}$ instrumenty związane z projektami przyjaznymi środowisku naturalnemu. W ujęciu geograficznym, 27\% emisji objęli inwestorzy z Niemiec i Austrii, 17\% z państw Beneluksu, 16\% z Wielkiej Brytanii i Irlandii, 15\% z krajów nordyckich, 13\% z Francji, 7\% z Polski oraz $5 \% \mathrm{z}$ pozostałych państw. Z punktu widzenia rodzaju instytucji, największy udział wśród inwestorów miały instytucje zarządzające aktywami (49\%), następnie banki (22\%), fundusze emerytalne i zakłady ubezpieczeń (16\%), banki centralne i instytucje publiczne (12\%) oraz pozostali inwestorzy (1\%) [Ministry of Finance 2017, s. 5].

Po nieco ponad roku od pierwszej emisji green bonds, polskie Ministerstwo Finansów z sukcesem uplasowało na rynkach zagranicznych drugą emisję zielonych obligacji. W lutym 2018 r. wyemitowano 8,5-letnie instrumenty z terminem zapadalności w sierpniu $2026 \mathrm{r}$. Ponownie popyt na polskie rządowe green bonds przewyższył zdecydowanie oczekiwania emitenta, osiągając wysokość 3,25 mld EUR, w efekcie czego kwota emisji została podwojona z planowanych $500 \mathrm{mln}$ EUR do 1 mld EUR. Dzięki temu uzyskano bardzo korzystne warunki wyceny tych obligacji - ich rentowność ukształtowała się na poziomie $1,153 \%$, przy rocznym kuponie na poziomie 1,125\% [List Emisyjny nr 20/2018]. W strukturze inwestorów, podobnie jak w pierwszej emisji, duży udział (ponad 40\%) mieli inwestorzy specjalizujący się w inwestycjach w aktywa sprzyjające środowisku. Większość nabywców tej emisji pochodziła z Europy, w tym z: Francji (23,5\%), Niemiec (19,0\%), Wielkiej Brytanii $(13,9 \%)$, Polski (9,6\%), Szwajcarii (5,0\%), krajów skandynawskich (4,8\%), Austrii $(3,9 \%)$, krajów Beneluksu $(1,9 \%)$, pozostałych $(8,1 \%)$. Udział inwestorów z USA wyniósł 3,5\%, Bliskiego Wschodu 2,0\%, a z pozostałych krajów 4,9\%. Ministerstwo podkreślało także znaczący udział inwestorów z Polski (ok. 10\%), co świadczy o rosnącym przekonaniu polskich podmiotów do inwestycji tzw. społecznie odpowiedzialnych. Jeśli chodzi o rodzaj instytucji nabywających polskie green bonds, to były to przede wszystkim podmioty zarządzające aktywami $(66,5 \%)$, w dalszej kolejności banki $(15,9 \%)$, banki centralne i instytucje publiczne $(9,2 \%)$, instytucje ubezpieczeniowe i fundusze emerytalne $(7,8 \%)$, fundusze hedgingowe $(0,3 \%)$ oraz pozostałe podmioty $(0,2 \%)$ [Ministerstwo Finansów 2018].

Głównym celem obu emisji zielonych obligacji jest finansowanie projektów mających korzystne oddziaływanie na środowisko naturalne, zgodnych z wymogami określonymi w dokumencie „Green Bond Framework” [The State Treasury of the Republic of Poland 2016]. Nie podano jednak konkretnych inwestycji, na które zostaną przeznaczone pozyskane środki, wskazano jedynie, że wpływy z emisji mogą być przeznaczone na sfinansowanie lub refinansowanie wydatków budżetowych na inwestycje przyjazne środowisku naturalnemu. 
Tabela 1. Charakterystyka emisji zielonych obligacji wyemitowanych przez polski rząd

\begin{tabular}{|c|c|c|}
\hline Parametry emisji & Emisja pierwsza & Emisja druga \\
\hline ISIN & XS1536786939 & XS1766612672 \\
\hline Data emisji & 20 grudnia 2016 & 7 lutego 2018 \\
\hline Termin zapadalności & 20 grudnia 2021 & 7 sierpnia 2026 \\
\hline Wartość nominalna & $750 \mathrm{mln}$ EUR & 1 mld EUR \\
\hline Wielkość popytu & 1,5 mld EUR & 3,25 mld EUR \\
\hline Cena nominalna & \multicolumn{2}{|c|}{1000 EUR } \\
\hline Cena sprzedaży & 993,43 EUR & 997,76 EUR \\
\hline Kupon roczny & $0,5 \%$ & $1,125 \%$ \\
\hline Uzyskana rentowność & $0,634 \%$ & $1,153 \%$ \\
\hline $\begin{array}{l}\text { Kierownicy konsorcjum } \\
\text { emisyjnego }\end{array}$ & $\begin{array}{l}\text { HSBC Bank plc, J.P. Morgan } \\
\text { Securities plc, PKO Bank Polski SA }\end{array}$ & $\begin{array}{l}\text { BNP Paribas, Citibank Global } \\
\text { Markets Limited, Commerzbank } \\
\text { Aktiengesellschaft, PKO Bank } \\
\text { Polski SA, Société Générale }\end{array}$ \\
\hline Agent emisji & \multicolumn{2}{|l|}{ Deutsche Bank AG, London Branch } \\
\hline Cel emisji & \multicolumn{2}{|c|}{$\begin{array}{l}\text { Pozyskanie środków na sfinansowanie potrzeb pożyczkowych budżetu } \\
\text { państwa, z przeznaczeniem na finansowanie projektów wskazanych } \\
\text { w Green Bond Framework z } 5 \text { grudnia } 2016 \text { r. }\end{array}$} \\
\hline Rating & $\begin{array}{l}\text { A (Dominion Bond Rating Service, } \\
08.12 .2017) \\
\text { A- (Fitch, 19.12.2016) } \\
\text { A2 (Moody's, 12.05.2017) } \\
\text { BBB+ (S\&P, 19.12.2016) } \\
\end{array}$ & $\begin{array}{l}\text { A (Dominion Bond Rating } \\
\text { Service, 08.02.2018) } \\
\text { A-(Fitch, 07.02.2018) } \\
\text { BBB+ (S\&P, 06.02.2018) }\end{array}$ \\
\hline Rynki notowań & \multicolumn{2}{|c|}{$\begin{array}{l}\text { Berlin Stock Exchange, Düsseldorf Stock Exchange, Frankfurt Stock } \\
\text { Exchange, Hamburg Stock Exchange, Hannover Stock Exchange, } \\
\text { London Stock Exchange Plc, Luxembourg Stock Exchange, Borsa } \\
\text { Italiana S.P.A., Munich Stock Exchange, Stuttgart Stock Exchange, } \\
\text { Tradegate Exchange }\end{array}$} \\
\hline
\end{tabular}

Źródło: opracowanie własne na podstawie: [List Emisyjny nr 67/2016; List Emisyjny nr 20/2018; Ministerstwo Finansów 2016; Ministerstwo Finansów 2018] oraz danych z serwisu informacyjnego Eikon na podstawie umowy pomiędzy firmą Thomson Reuters a Uniwersytetem Gdańskim.

Wspomniany dokument „Green Bond Framework” został opracowany przez Ministerstwo Finansów przed pierwszą emisją polskich zielonych obligacji na podstawie międzynarodowych standardów opublikowanych przez International Capital Market Association [International Capital Market Association 2016]. Jest to kilkustronnicowy dokument ramowy, w którym wskazano, jakie projekty czy rodzaj działalności mogą zostać sfinansowane środkami pochodzącymi z emisji zielonych obligacji, a także które nie są do tego uprawnione wraz ze wskazaniem zasad oceny i wyboru projektów. Środki z emisji green bonds mogą, zatem, finansować projekty z zakresu zrównoważonego rolnictwa, czystego transportu, odnawialnych źródeł energii, zalesiania terenów, funkcjonowania parków narodowych oraz rekultywacji zdegradowanych terenów. Wpływy ze sprzedaży zielonych obligacji nie mogą być 
natomiast kierowane do projektów oraz podmiotów związanych z energią jądrową, paliwami kopalnymi, produkcją/dostarczaniem broni, alkoholu, gier hazardowych czy rozrywki dla dorosłych. Ponadto w dokumencie zawarto wytyczne w zakresie zarządzania środkami pochodzącymi z emisji zielonych obligacji oraz raportowania na temat ich wykorzystania [The State Treasury of the Republic of Poland 2016, s. 2,3].

W momencie powstawania niniejszego opracowania znane były szczegóły wykorzystania wpływów jedynie z pierwszej emisji polskich green bonds. W niespełna rok od emisji wydatkowana została całość pozyskanych środków, w tym $80,6 \%$ wartości emisji celem refinansowania wydatków poniesionych w latach 2014-2016, a 19,4\% przeznaczono na finansowanie projektów zainicjowanych w I kwartale 2017 roku. Środki te alokowano na projekty reprezentujące każdy sektor wskazany w „Green Bond Framework”, przy czym najwięcej przeznaczono na projekty z zakresu zrównoważonego rolnictwa (292,1 mln EUR, 39\%), czystego transportu (241,3 mln EUR, 32\%) oraz odnawialnych źródeł energii (155,2 mln EUR, 21\%), następnie na parki narodowe (35,4 mln EUR, 5\%), zalesianie (21,0 mln EUR, 3\%) i rekultywację terenów (0,02 mln EUR) [Ministry of Finance 2017, s. 11]. Warto także wspomnieć, że za pionierską emisję obligacji Polska została uhonorowana kilkoma nagrodami, w tym m.in. nagrodą Green Bonds Pioneer Awards przyznawaną przez władze londyńskiej dzielnicy City wraz z dwoma organizacjami: International Capital Market Association (ICMA) oraz Climate Bonds Initiative (CBI).

\section{Analiza porównawcza polskich skarbowych green bonds oraz klasycznych obligacji zagranicznych}

W badaniu przeprowadzonym w niniejszym opracowaniu wykorzystano wskaźniki rentowności obligacji, tj. rentowność bieżącą (current yield, CY), rentowność w terminie do wykupu (yield to maturity, YTM), jak również ceny tych instrumentów. Dane do badania zaczerpnięto z serwisu informacyjnego Eikon Thomson Reuters (rodzaj: daily, last, mid). W pierwszym etapie analizy dokonano porównania dwóch opisanych powyżej emisji polskich green bonds, a w kolejnym zestawiono analizowane wskaźniki zielonych obligacji z klasycznymi, „niezielonymi” skarbowymi obligacjami wyemitowanymi na rynkach zagranicznych (do analizy zostały wybrane papiery dłużne, które mają taki sam rok wykupu oraz zbliżony termin emisji: zielona EUR20260807: 7.02.2018-7.08.2026 i odpowiadająca jej EUR20260119: 18.01. 2016-19.01.2026; zielona EUR20211220: 20.12.2016-20.12.2021 i odpowiadająca jej EUR20211014: 14.10.2015-14.10.2021).

Analiza porównawcza podstawowych wskaźników rentowności dwóch emisji zielonych obligacji objętych badaniem wskazuje, że niezależnie, czy weźmie się pod uwagę rentowność bieżącą, czy rentowność do wykupu, wyższe wartości zaobserwowano w odniesieniu do obligacji z drugiej emisji, tj. EUR20260807 (rys. 1). Śred- 


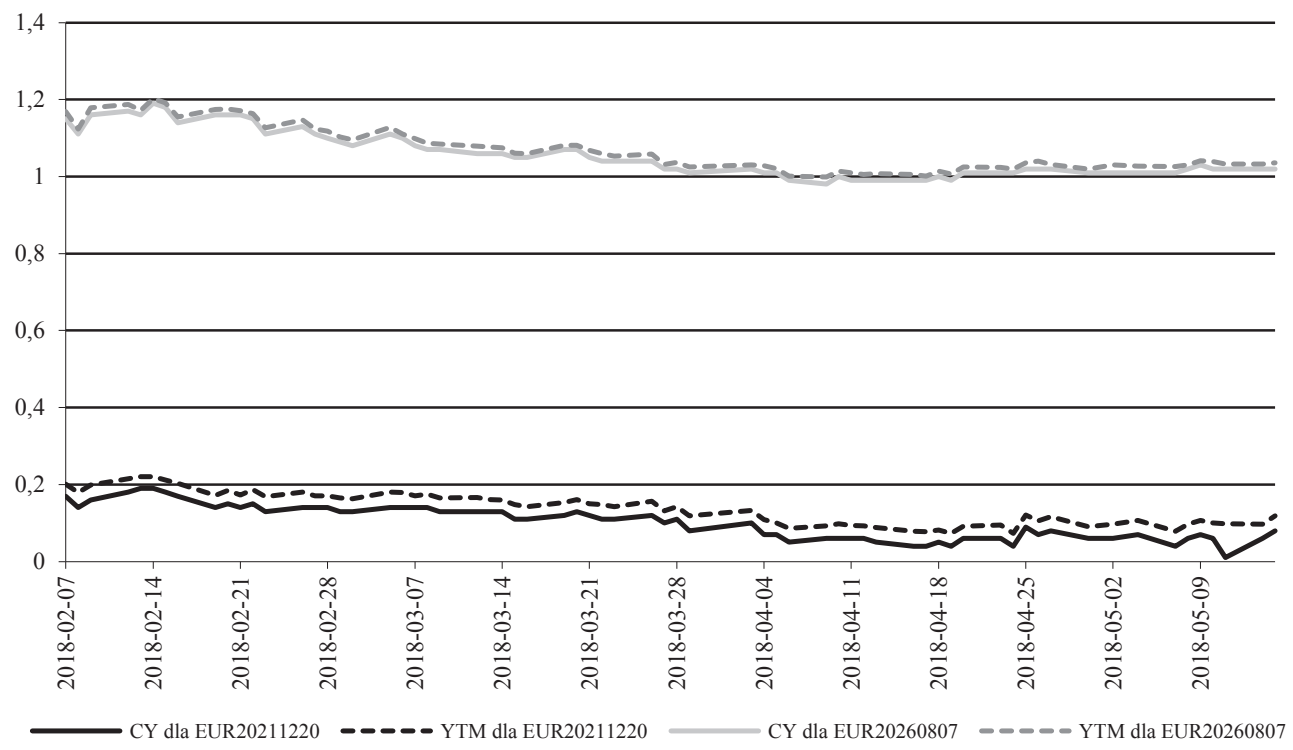

Rys. 1. Wskaźniki: CY, YTM dla zielonych obligacji: EUR20260807 oraz EUR20211220 w okresie 7.02.2018-15.05.2018

Źródło: opracowanie własne na podstawie danych z serwisu informacyjnego Thomson Reuters na podstawie umowy pomiędzy Uniwersytetem Gdańskim a firmą Thomson Reuters.

nia różnica w przypadku wskaźnika CY pomiędzy zielonymi obligacjami wyniosła $0,95 \%$ (max $1,02 \%$, min $0,91 \%)$, a biorąc pod uwagę YTM $0,93 \%(\max 1,02 \%, \min$ $0,89 \%)$.

W przypadku obu papierów dłużnych do połowy kwietnia 2018 roku można było zauważyć trend wzrostowy, przy czym relatywnie wyższymi cenami cechowała się obligacja EUR20211220 (z pierwszej emisji), natomiast wyższą dynamiką wzrostu cen obligacja EUR20260807 (rys. 2). Porównanie 1-dniowej zmiany cen obu papierów wskazuje na średnią dla obligacji EUR20260807 na poziomie 0,01616\%, a dla EUR20211220 w wysokości 0,00318\%. Maksymalna 1-dniowa zmiana ceny EUR20211220 w ujęciu bezwzględnym to 0,19\%, natomiast dla EUR20260807 to $0,45 \%$, a minimalna w obu przypadkach oscylowała wokół $0 \%$.

W okresie objętym analizą wyższy poziom wskaźnika benchmark spread był odnotowywany w odniesieniu do obligacji EUR20260807.

Badanie struktury inwestorów, którzy nabyli zielone obligacje, wykazało, że są to głównie firmy zarządzające aktywami, pochodzące przede wszystkim z Niemiec, Austrii, Wielkiej Brytanii, Francji, Luksemburga, Holandii, USA, Belgii, Szwajcarii, Irlandii. Niektóre z nich, takie jak: BlackRock Advisors (UK) Limited (różne portfele), BlackRock Financial Management, Inc (ten sam portfel), BlackRock Investment Management (UK) Ltd (różne portfele), Kredietrust Luxembourg SA (ten 


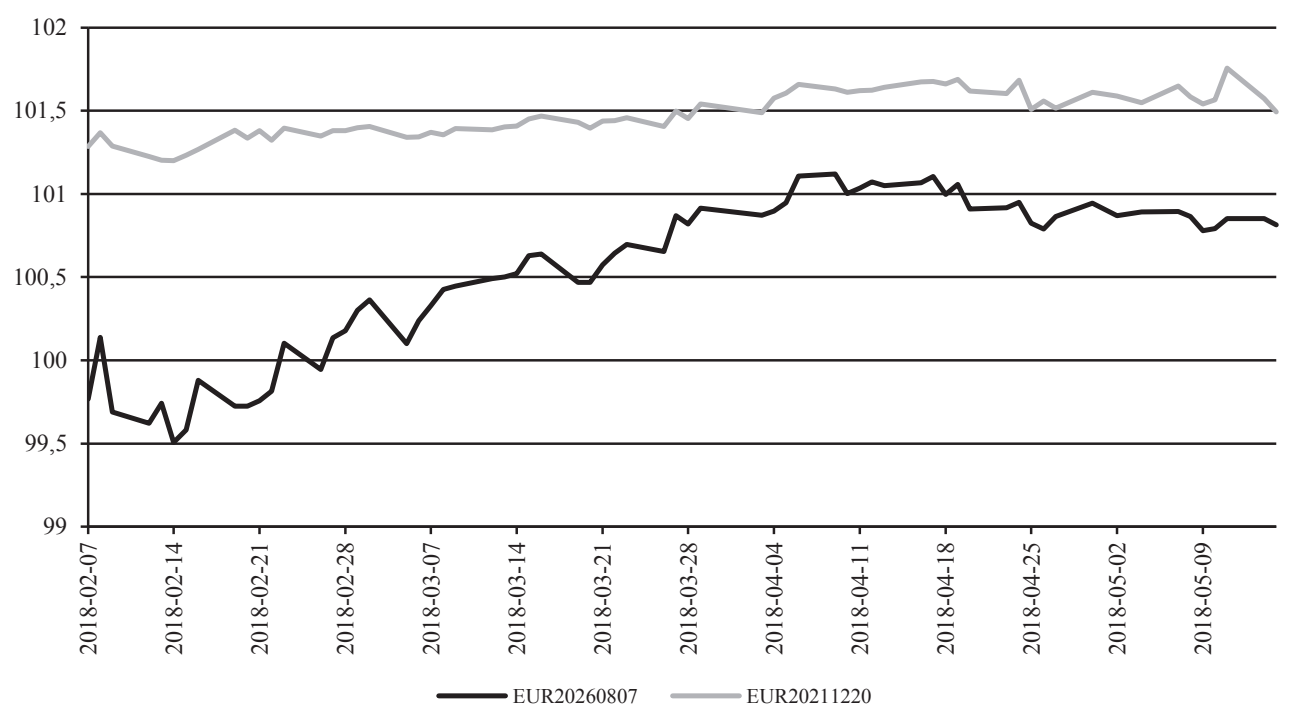

Rys. 2. Ceny zielonych obligacji: EUR20260807 oraz EUR20211220 w okresie 7.02.2018-15.05.2018 Źródło: jak na rys. 1.

sam portfel), Natixis Asset Management (różne portfele), objęły obie emisje zielonych obligacji. Ponadto $\mathrm{w}$ gronie inwestorów, posiadających green bonds $\mathrm{z}$ każdej emisji znalazły się podmioty należące do tej samej grupy kapitałowej, tj. Amundi, BNP Paribas. Jedynym polskim podmiotem, który nabył obligacje zielone, był BZ WBK AIB Asset Management SA (EUR20211220).

Analiza porównawcza zielonych obligacji do „niezielonych” zagranicznych obligacji skarbowych w przypadku pary: EUR20211220 i EUR20211014 prowadzi do wniosku, że tylko do połowy kwietnia 2018 r. green bonds charakteryzowały się wyższym poziomem YTM, przy czym różnica w wysokości tego wskaźnika dla obu papierów sukcesywnie spadała (rys. 3). W odniesieniu do pary EUR20260807 i EUR20260119 także zauważalny był wyraźny spadek spreadu pomiędzy green bonds a klasyczną obligacją skarbową, jednak w tym krótkim okresie, którego dotyczy badanie, nie doszło do sytuacji, w której wskaźnik YTM dla obligacji zielonej byłby relatywnie niższy (rys. 4). Relatywna przewaga obligacji zielonych, biorąc pod uwagę ten wskaźnik, była najwyższa w pierwszej połowie okresu analizy. Następnie zaczęła wyraźnie maleć.

Ceny zielonych obligacji oraz klasycznych zagranicznych obligacji skarbowych objętych analizą zachowywały się podobnie, jeżeli chodzi o kierunek zmiany. Ponadto badanie 1-dniowej zmiany ich cen (w odpowiednich parach papierów dłużnych) nie wykazało pomiędzy nimi istotnych różnic (tab. 2). Ceny obu obligacji zielonych były zawsze niższe od cen ich odpowiedników. 


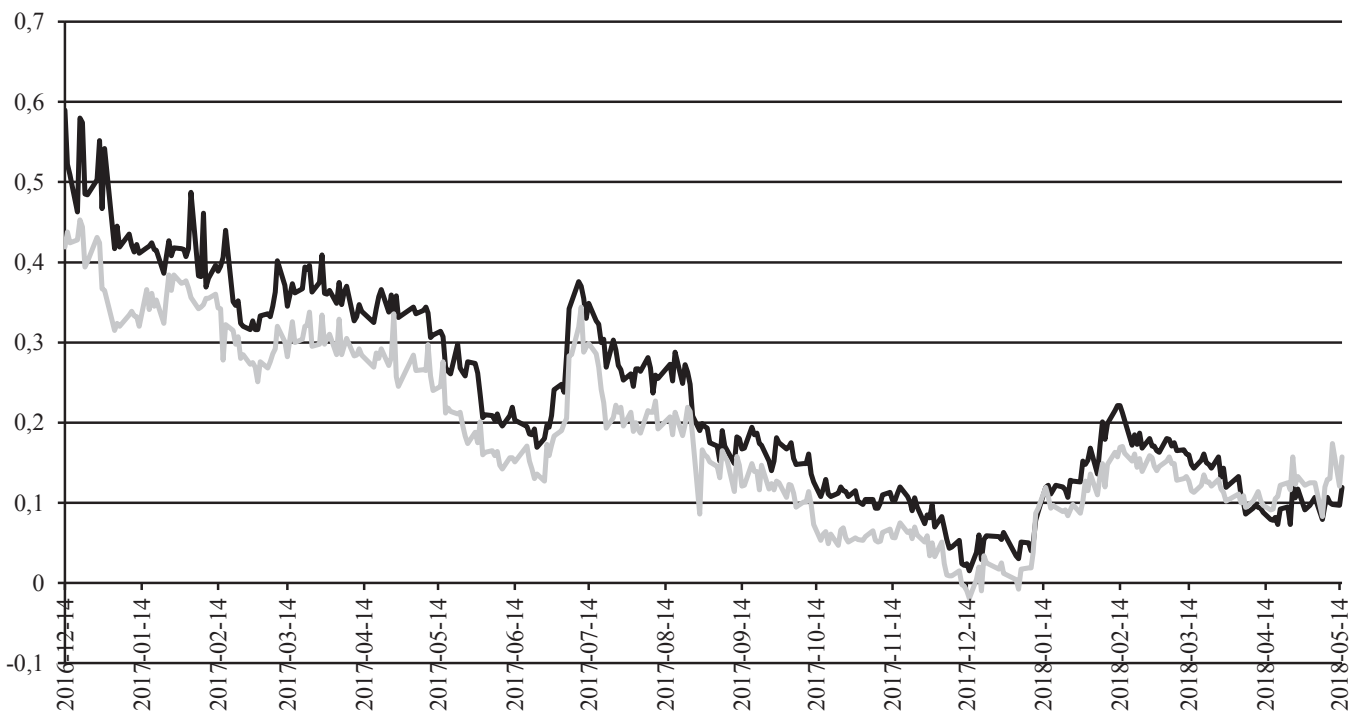

Rys. 3. YTM dla obligacji EUR20211220 oraz EUR20211014 w okresie 20.12.2016-15.05.2018 Źródło: jak na rys. 1.

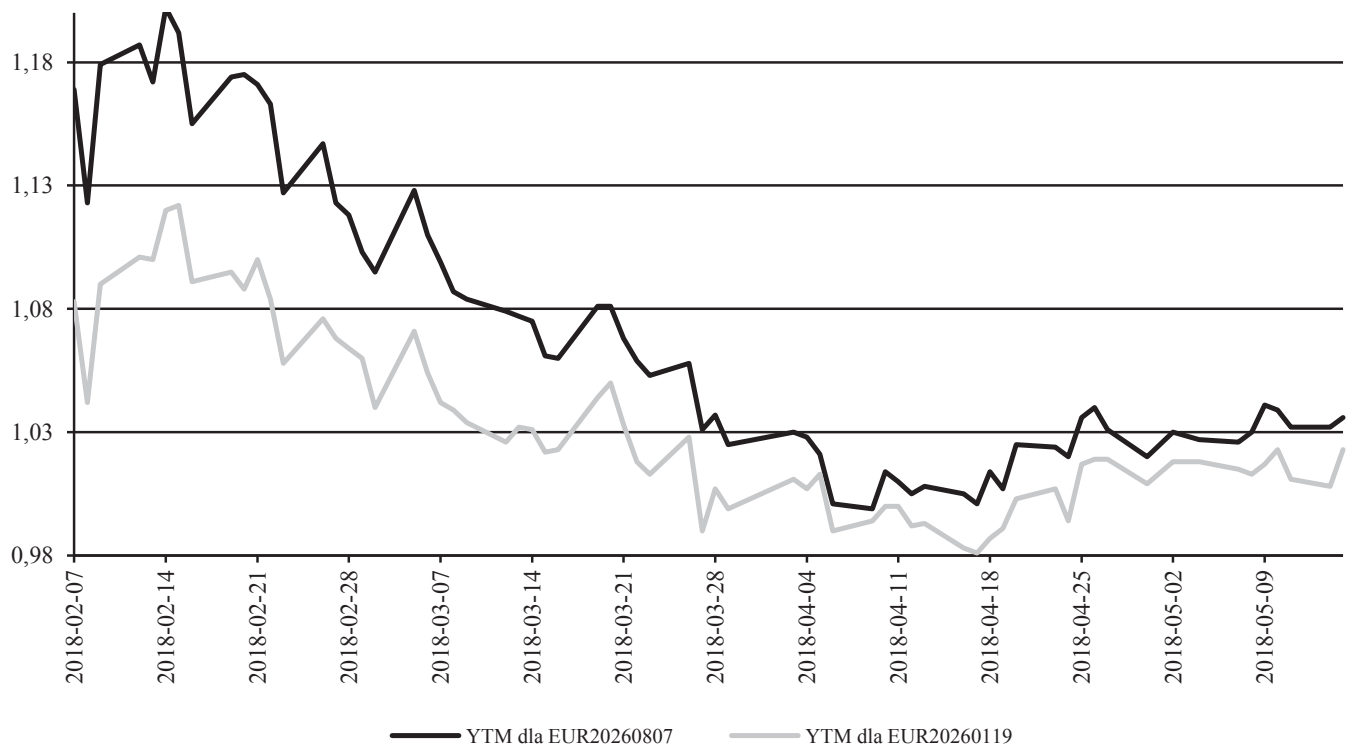

Rys. 4. YTM dla obligacji EUR20260807 oraz EUR20260119 w okresie 7.02.2018-15.05.2018 Źródło: jak na rys. 1. 
Tabela 2. 1-dniowa zmiana ceny dla pary obligacji: EUR20211220 i EUR20211014 (dla okresu: 20.12.2016-15.05.2018) oraz pary obligacji EUR20260807 oraz EUR20260119 (dla okresu: 7.02.2018-15.05.2018)

\begin{tabular}{|l|c|c|c|c|}
\hline \multicolumn{1}{|c|}{ Obligacja } & Max (\%) & Min (\%) & Średnia (\%) & $\begin{array}{c}\text { Średnia ze zmian } \\
\text { bezwzględnych (\%) }\end{array}$ \\
\hline EUR20211220 & 0,41 & 0 & 0,00431 & 0,05983 \\
\hline EUR20211014 & 0,40 & 0 & 0,00124 & 0,05875 \\
\hline EUR20260807 & 0,45 & 0,00099 & 0,02 & 0,09 \\
\hline EUR20260119 & 0,36 & 0,00096 & 0,01 & 0,08 \\
\hline
\end{tabular}

Źródło: opracowanie własne na podstawie danych z serwisu informacyjnego Eikon na podstawie umowy pomiędzy firmą Thomson Reuters a Uniwersytetem Gdańskim.

Charakterystyka porównawcza inwestorów nabywających zielone obligacje EUR20260807 i EUR20260119 wykazała, że trzej z nich to posiadacze obu papierów (Allianz Invest Kapitalanlagegesellschaft mbH, BlackRock Advisors (UK) Limited, ERSTE-SPARINVEST Kapitalanlagegesellschaft mbH). W przypadku pary obligacji: EUR20211220 i EUR202111014 byli to z kolei: BNP Paribas Investment Partners UK Limited, External Manager Not Disclosed (North America), MEAG Munich ERGO Kapitalanlagegesellschaft $\mathrm{mbH}$, Raiffeisen Kapitalanlage-Gesellschaft mbH, Union Investment Privatfonds Gmb [Eikon].

\section{Zakończenie}

Przeprowadzona analiza wykazała, że w okresie od momentu emisji „młodszej” z zielonych obligacji do połowy maja 2018 r. papier z terminem wykupu w 2026 roku cechował się wyższymi wartościami wskaźników: CY, YTM oraz spread benchmark (co wynikało z relatywnie niższych cen tego instrumentu finansowego). 1-dniowa zmiana cen na zamknięciu (last) była wyższa także w przypadku papieru o późniejszym terminie wykupu (biorąc pod uwagę poziom zarówno średni, jak i maksymalny). Na skutek relatywnie silniejszego wzrostu cen do połowy kwietnia 2018 r. spadała różnica pomiędzy cenami obu obligacji zielonych.

Przyjęta w opracowaniu hipoteza została zweryfikowana pozytywnie, bowiem obligacje zielone cechowały się, podczas prawie całego okresu analizy, wyższymi poziomami wskaźnika YTM niż ich „niezielone” odpowiedniki, czyli zagraniczne obligacje skarbowe o zbliżonym czasie życia. Tylko EUR20211220 od połowy kwietnia 2018 roku zaczęła charakteryzować się relatywnie niższym YTM. Należy jednak wskazać na tendencję spadkową - malała nadwyżka YTM dla obu obligacji zielonych. Ceny obligacji zielonych i „niezielonych” różniły się od cen z dnia poprzedniego w ujęciu procentowym w podobny sposób (badanie 1-dniowej zmiany cen nie wykazało istotnych różnic). Niektórzy inwestorzy nabyli jednocześnie obligacje zielone i objęte badaniem „niezielone” skarbowe obligacje zagraniczne.

Pierwsza polska emisja obligacji skarbowych klasyfikowanych jako green bonds stała się ważnym wydarzeniem na światowych rynkach finansowych inaugurującym 
nowy segment instrumentów dłużnych, tj. sovereign green bonds. W ten sposób Polska trwale wpisała się w historię rozwoju rynków finansowych, umacniając dodatkowo swoją pozycję lidera kolejną emisją tych instrumentów, stając się tym samym pierwszym na świecie państwem emitującym ten typ papierów wartościowych dwukrotnie. Bardzo duże zainteresowanie inwestorów obiema emisjami polskich green bonds potwierdziło, że istnieje zapotrzebowanie na instrumenty finansowe związane z projektami przyjaznymi środowisku naturalnemu. Popyt ten jest efektem poszukiwania przez inwestorów nowych źródeł dywersyfikacji portfeli inwestycyjnych, ale wynika także z coraz większej świadomości ludzi o potrzebie ochrony środowiska naturalnego i konieczności konsekwentnego realizowania idei zrównoważonego rozwoju.

Z punktu widzenia Polski, emisja zielonych obligacji nie tylko umożliwiła poszerzenie bazy inwestorskiej czy stanie się pionierem na rynkach finansowych, ale wiązała się także z podkreśleniem, że polskie władze wspierają projekty korzystne dla środowiska naturalnego oraz finansują kluczowe cele środowiskowe kraju, określone m.in. w dokumentach przyjętych przez Radę Ministrów: z 7 grudnia 2010 r. pt. „Krajowy Plan Działania w zakresie energii ze źródeł odnawialnych” oraz z 23 czerwca 1995 r. pt. „Krajowy Program Zwiększania Lesistości”. Działania polskiego rządu wpisują się, zatem, w unijną politykę zrównoważonego finansowania na rzecz zrównoważonego rozwoju i bardziej ekologicznej gospodarki.

\section{Literatura}

Bieliński T., Mosionek-Schweda M., 2018, Green Bonds as a financial instrument for environmental projects funding, Unia Europejska.pl, nr 1(248).

European Commission, 2018, Financing a Sustainable European Economy, High-Level Expert Group on Sustainable Finance, Brussels.

International Capital Market Association, 2016, Green Bond Principles, https://www.icmagroup.org/ green-social-and-sustainability-bonds/green-bond-principles-gbp/ (20.05.2018).

List Emisyjny nr 20/2018 Ministra Finansów z dnia 5 lutego 2018 r. w sprawie emisji obligacji ośmioletnich o oprocentowaniu stałym i terminie wykupu w dniu 7 sierpnia 2026 r., oferowanych na rynkach zagranicznych.

List Emisyjny nr 67/2016 Ministra Rozwoju i Finansów z dnia 16 grudnia 2016 r. w sprawie emisji obligacji pięcioletnich o oprocentowaniu stałym i terminie wykupu w dniu 20 grudnia $2021 \mathrm{r}$., oferowanych na rynkach zagranicznych.

Ministerstwo Finansów, 2016, Polska pierwszym państwem emitującym zielone obligacje, Komunikat z dnia 12.12.2016, https://www.mf.gov.pl/ministerstwo-finansow/dla-mediow/informacje-prasowe/-/asset_publisher/6PxF/content/id/5855504 (20.05.2018).

Ministerstwo Finansów, 2018, Polska po raz drugi wyemitowała obligacje Green Bonds, Komunikat z dnia 06.02.2018, https://www.mf.gov.pl/ministerstwo-finansow/wiadomosci/aktualnosci/-/asset_publisher/M1vU/content/id/6279990 (20.05.2018).

Ministry of Finance, 2017, Green Bond Report on the Use of Proceeds. Poland's Green Bond EUR 5-year maturing on 20 December 2021, Warsaw.

The State Treasury of the Republic of Poland, represented by the Minister of Development and Finance, Green Bond Framework, 5th December 2016. 